\title{
Overview of cost-effectiveness analysis and health state utilities in multiple myeloma and estimations of health state utilities from real-world macedonian data
}

\author{
Vjollca Qerimi 1,2,*, Aleksandra Kapedanovska Nestorovska ${ }^{1}$, Zoran Sterjev ${ }^{1}$, \\ Sonja Genadieva-Stavric ${ }^{3}$, Ljubica Suturkova ${ }^{1}$
}

\author{
${ }^{1}$ Faculty of Pharmacy, Ss. Cyril and Methodius University in Skopje, Majka Tereza 47, 1000 Skopje, Macedonia \\ ${ }^{2}$ Institute of Public Health, Medical Decision Making and Health Technology Assessment, Department of Public Health, \\ Health Services Research and Health Technology Assessment, UMIT - University for Health Sciences, \\ Medical Informatics and Technology, Eduard-Wallnöfer-Zentrum 1, 6060 Hall i.T., Austria \\ ${ }^{3}$ Medical Faculty, University Hematology Clinic, Mother Thereza 471000 Skopje, Macedonia
}

Received: September 2016; Accepted: October 2016

\begin{abstract}
Multiple myeloma (MM) is a hematological neoplastic plasma-cell disorder in the bone marrow. Nowadays, the survival of MM patients has improved by using novel therapies (e.g., bortezomib, thalidomide). Decision-analytic models (DAM) are known to be very useful in guiding clinical and health policy decisions by systematically evaluating expected outcomes of alternative treatments. When conducting DAM, it is recommended by National Institute for Clinical Excellence (NICE) as the preferred framework to use qualityadjusted life years as the main measure for health outcomes derived from generic preference-based instruments.

The objective of our study was to identify and analyze the structural and methodological approaches of published studies that evaluated: (1) DAM for various treatment strategies in MM and (2) published health utility values (HUVs) after MM treatment. The searches were developed in the electronic literature database PubMed/MEDLINE. Additionally, we aimed to derive real-world data for HUVs from the current patients' treatment landscape in the Hematology Clinical Center in Skopje. The survey collecting national HUVs was conducted during the period January-November 2016, using the generic preference-based instrument EQ-5D-5L, administered at one-time point in $20 \mathrm{MM}$ patients.

Only five studies reported on using a DAM. Seven studies were included in the extraction of already published HUVs. The calculated national health utility score of 0.723 was comparable to the published data in the previously identified studies reporting on similar MM treatment protocols. Several modeling approaches and HUVs, developed for different treatment strategies and target groups in MM were identified. Those data could be used to parameterize a DAM for MM treatment.
\end{abstract}

Keywords: Health utility value, multiple myeloma, decision-analytic models, utility, EQ-5D-5L

\section{Introduction}

Multiple myeloma (MM) is a hematological neoplastic plasma cell disorder characterized by clonal proliferation of plasma cells that are malignant in the bone marrow, monoclonal protein in the blood or urine and several organ dysfunction (anemia, bone disease and renal failure) (Blade et al., 1998; Palumbo and Anderson, 2011). Based on the published literature, the average age at diagnosis for MM is

\footnotetext{
*vjollca.qerimi@umit.at
} 
70 years, where $37 \%$ of patients are younger than 65 years, and the rest are aged above 65 years (Howlade, Noone and Krapcho, 2011; Palumbo and Anderson, 2011).

When considering the quality-of-life impact and life expectancy, the MM is considered as a severe disease and there is still no cure. However, in the past decade, the survival of MM patients has remarkably increased due to the introduction of novel ('targeted') therapies, such as bortezomib, thalidomide, and lenalidomide. The novel therapies have also shown improvements in the use of autologous stem cell transplantation (ASCT) and supportive therapy (Kumar et al., 2012; Moreau et al., 2013; Moreau and Touzeau, 2015; Palumbo et al., 2011; Palumbo et al., 2014; Stojanoski et al., 2013). Nowadays, the newly diagnosed patients expect to live on average for 5-7 years, with some exceptional cases living longer than 10 years (Howlade, Noone and Krapcho, 2011).

Additionally, the novel agent based therapies in MM resulted in reliable improvements in health outcomes, and led to the development of new treatment combinations that usually result in different benefits, side effects as well as higher costs (Moreau et al., 2013; Palumbo et al., 2011; Palumbo et al., 2014; Stojanoski et al., 2013). The conventional therapeutic combination includes steroids, chemotherapy, as well as stem cell transplantation (SCT); those resulting in unique profiles when compared with the previous standard of care. The treatment combinations are cytostatic drugs and steroids (as melphalan, prednisone) with one or two novel agents (e.g., bortezomib, thalidomide, lenalidomide). However, with the new treatment regimens, patients are expected to experience different adverse drug events (such as: anemia, thrombocytopenia, neutropenia, lymphopenia, neuralgia, neuropathy, pneumonia, constipation, diarrhea, fatigue, nausea/vomiting, deep-vein thrombosis, etc.) that could lead to higher costs (Blade et al., 1998; Moreau et al., 2013; Moreau and Touzeau, 2015; Palumbo et al., 2011; Palumbo et al., 2014; Stojanoski et al., 2013).

Decision-analytic modeling studies are known of a big assistance in guiding clinical and health policy decisions as they systematically evaluate expected outcomes of different treatment options that are compared by considering benefits and harms at the same time, as well as the treatment related costs (Hunink et al., 2001). Several mathematical models, with different structural and methodological approaches, have been identified in the previously published reviews, comparing clinical outcomes of different treatment strategies and combinations in $\mathrm{MM}$ treatment regimens (Rochau et al., 2015). This led to different recommendations on what is the best model to use in MM that would include all the treatment lines and all the morphological and structural aspects towards developing a good cost-effectiveness model.

When conducting economic evaluations, National Institute for Clinical Excellence (NICE) recommends as the preferred framework to use quality-adjusted life years (QALYs) as the main measure for health outcomes. There are several methods and questionnaires available for measuring health or health-related quality of life (HRQoL), separated as a generic preference-based instrument (EQ-5D, SF-6D, HUI) and non-preference instruments (condition-specific, disease specific, clinical indicators of disease severity, etc.). Deriving utilities from a generic preference-based instrument is the first choice as NICE recommends. However, in most cases, clinical trials do not include preference-based questionnaires. In cancerrelated research, non-preference based disease-specific questionnaires are most frequently used to measure HRQoL (Longworth and Rowen, 2013).

The aim of our literature review is to identify different modeling approaches of already published costeffectiveness analysis for various treatment strategies in MM and to derive health utility values (HUVs) from already published clinical relevant studies. Additionally, we aimed to give an insight into the real-world data for HUVs from the current patients' treatment landscape in the Hematology Clinical Center in Skopje, using the EuroQol five dimensions questionnaire (Group, 2014).

\section{Material and methods}

Two independent systematic literature searches (SLSs) in the electronic literature database PubMed/MEDLINE were performed. The aim of the primary search was to find relevant data on decision-analytic modeling studies for MM treatment during the period 2000-2015, and the aim of the secondary search was to find relevant data on HRQoL for MM treatment. Additionally, a one-time EQ-5D-5L questionnaire was implemented in the patients treated with MM in Macedonia, as described in the following sections.

\section{Systematic literature search for identifying economic evaluations}

During November 2015 a SLS was conducted to identify already published cost-effectiveness analysis that compared different treatment combinations for MM patients. The search was done in PubMed/MEDLINE, with applying the keywords as in the Appendix A.1. To identify the most recent published models, the search was restricted on an abstract/title search, humans and full-text filters, date of publication (2010-2015), and language (English). All studies that reported decision-analytic model for MM treatment (possibly for the first line treatment and prior to SCT) were published as full texts, in English language, and were not older than 2010. Overall, 76 studies were identified in the systematic search. After two phases of screening, only five studies were included in the full analysis (Fig. 1).

The extracted characteristics of each model in the published studies included in the search were based on the Modeling Good Research Practices Guidelines, such as the ISPOR-SMDM Modeling Good Research Practices 
Task Forces 1, 2, 3,6 and 7 and the Consolidated Health Economic Evaluation Reporting Standards (Husereau et al.) (Briggs, A. et al., 2012; Caro et al., 2012; Eddy et al., 2012; Husereau et al., 2013; Roberts et al., 2012; Siebert et al., 2012).

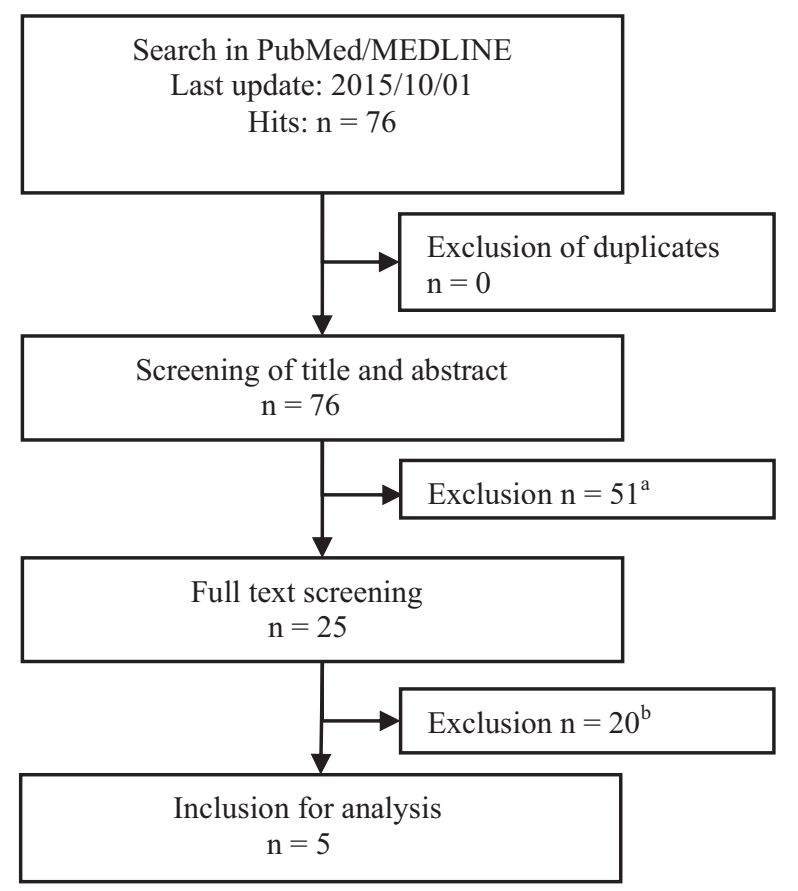

Fig. 1. The flow diagram of the systematic literature search for published decision-analytic models in multiple myeloma ('Excluded studies - did not report cost-effectiveness analysis or modeling techniques in the abstract/titile; for other diseases and not for multiple myeloma treatment; not published in English; ${ }^{b}$ Excluded studies - did not report cost-effectiveness analysis or modeling techniques for multiple myeloma treatment; or were not available as full text).

\section{Systematic literature search on health state utility values data}

Additionally, the second SLS was performed (during December 2015 - February 2016), using the electronic literature database PubMed/MEDLINE to find relevant published data on health state utility values for MM treatment. The studies were screened using the following inclusion criteria: 1) studies evaluating treatment strategies for MM; 2) studies published as a full-text; and 3) studies reporting utilities from the EQ-5D questionnaire. In the search, the combination of keywords as explained in Appendix A.2 was used. Data from each study were extracted separately and the utility values they reported as well as study references (as far as available). Overall, from the literature search for the utility parameter identification,
459 studies were identified. After two phases of screening, only seven studies were included for further extraction and analysis (Fig. 2).

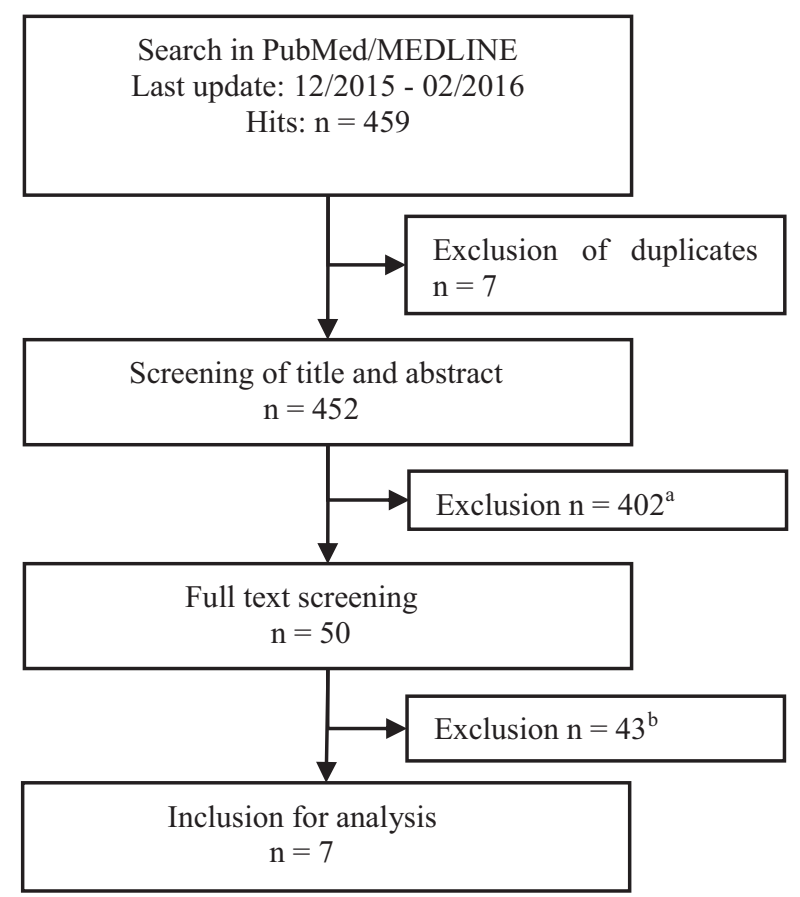

Fig. 2. The flow diagram of the systematic literature search on identifying health utility parameters from published studies for multiple myeloma

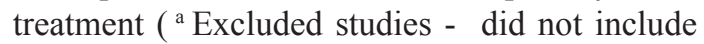
an evaluation of a health utility measure for MM treatment in the abstract/title; or did not report the use of the EQ-5D questionnaire; reported health utility parameters for other diseases; were not published in English; ${ }^{\mathrm{b}}$ Excluded studies - did not report health utility parameters for multiple myeloma; or not available as full text).

\section{Utility assessments from EQ-5D-5L questionnaire (macedonian real-world data)}

The HRQoL from the real-world Macedonian data was assessed using the generic preference-based instrument the 5-level EQ-5D version (Group) (Appendix B). The EQ$5 \mathrm{D}-5 \mathrm{~L}$ is a standardized, generic HRQoL questionnaire that can be converted into a 'health utility' score questionnaire used to measure health outcomes, particularly in health economic evaluations. The EQ-5D-5L consists of two pages: the EQ-5D descriptive system and the EQ visual analogue scale (VAS). The descriptive system measure HRQoL in five dimensions: mobility, self-care, usual activities, pain/discomfort and anxiety/depression (Group, 1990).

Participants are asked to indicate their current level of health by checking one of five boxes for each domain 
ranging from no problems to extreme or severe problems (no problems, slight problems, moderate problems, severe problems, and extreme problems). Responses to the five domains are used to derive health utilities, which represent preferences for different health states and when combined with life duration information, enable the calculation of QALYs for economic evaluations. Health utility scores can be in a range between 1 and 0 , where a score of 1 represents full health, and 0 represents death. In addition to the five domains, participants also rate their current health on a scale of 0 to 100 (100 means 'The best health you can imagine' and 0 means 'The worst health you can imagine') on a VAS (Group, 1990).

The survey collecting HUVs was conducted during the period January-November 2016 in the Hematological Clinical Center in Skopje and was administered at one-time point. All patients, with a self-reported diagnosis of MM, were eligible for inclusion. The survey was completed by 20 patients that were hospitalized for MM treatment and was self-evaluated. The therapeutic landscape included treatment with thalidomide-based and bortezomib-based combinations as induction therapy prior to ASCT. To convert the HRQoL data from the EQ-5D-5L questionnaire into a 'health utility' value, standardized EQ-5D-5L Index Value Calculator was used, developed by the EuroQol Group (Version 1), calculated with the Spain EQ-5D-5L Value Set. As Macedonia was not in the list of countries available within the index value calculator (Denmark, Spain, France, Germany Japan, Netherland, Thailand, UK, US and Zimbabwe), and there are no specific requirements or preferences in regard to the methodology for vauing the general population value sets in decision makaing for Macedonia, it was assumed that from countries with available value set the Spain as a mediteranian country has most closely approximate population characteristics of Macedonia.

\section{Results}

\section{Decision-analytic models identified}

From the identified studies, several decision-analytic model types were used to answer the decision problem addressed in the relevant study. An overview of the extracted data is shown in Table 1 and Table 2.

In the review, only one study used a decision tree in order to model the research question (Pandya et al., 2014). Pandya et al. applied a decision tree to compare early ASCT vs. delayed ASCT strategies in MM to estimate the cost-effectiveness relation between the two strategies. This analysis evaluated early vs. delayed ASCT, without incorporating the maintenance therapy in either in the earlier or delayed group (Pandya et al., 2014). The authors did not report the reason for choosing the decision tree as most appropriate for their problem; one can assume that the relatively short time horizon starting from early ASTC (performed within 12 months of diagnosis) and delayed group (patients who had ASCT performed any time after 12 months of diagnosis) was the reason for choosing the framework of the decision tree model. The decision tree is known as a "schematic of all the essential components of a decision problem, including the possible pathways, the consequences, and their respective probabilities" (Hunink et al., 2001). Even though decision trees can be developed easy, structured and also modified without too many efforts, they can have several limitations when used for longer time horizons; as defined based on the ISPORSMDM Task Forces: "they are most suitable when the outcome set is small and defined, the time horizon is short, or when the consequences of a decision are known with some certainty" (Roberts et al., 2012).

For many diseases, such as chronic diseases (as MM), where the disease itself can change over time, progress, relapse or even show no event, it is very difficult to model and include all the events that change over time. In those cases, the model parameters can change over time and it is important to consider the time to change events and the possibility of a recurrence of an event as well as the transition from one state to another. To model those events, the researchers in the field of decision-analytic modeling have explored and developed Markov models. Markov model was developed in only one study (Garrison et al., 2013). In the Garrison et al. study, in which previously untreated transplant ineligible MM patients were included, the model was used to determine the most cost-effective combination as a first-line therapy, bortezomib, prednisone or lenalidomide. The model was constructed considering seven health states for MM, such as: response status, treatment-free/maintenance treatment, progressive disease, and death (Garrison et al., 2013). However, to estimate health outcomes in a cost-effectiveness study while using Markov model could also add more complexity to the framework, thus may be the reason why it is rarely used (Hunink et al., 2001).

Blommstein et al. used a patient-level simulation (PLS) model to model the cost-effectiveness of melphalanprednisone (MP), thalidomide-based, bortezomib-based, lenalidomide-based and other treatments in elderly ( $\geq 66$ years) patients with MM (Blommestein et al., 2016). PLS model is a model based on the discrete event simulation models that focus on patients individual characteristics and events while memorizing the treatment history and patient characteristics over time (Caro, 2005). Those models are "characterized by the ability to represent interactions between individuals, populations, and their environments", where the model simulations can move forward in time from one event to the next one (Karnon et al., 2012).

In the actual review, two studies used survival partitioned models (SPMs) (Cooper et al., 2014; Picot et al., 2011). In those models, the model is used to follow a theoretical cohort through time as they move between a set of exhaustive and mutually exclusive health states. 
These types of models are frequently used to model cancer treatments, with separate survival equations for overall survival and progression-free survival. Common functions used to describe survival are exponential, Weibull or Gaussian (amongst others). Picot et al. used an SPMs to estimate the mean difference in overall survival and progression-free survival between the interventions and to calculate the time spent in three health states: treatment, post-treatment and progression (Picot et al., 2011).

Time horizons: The time horizon of the model "should be long enough to capture important and relevant differences in outcomes between the strategies", based on the guidelines for good practice in decision-analytic modeling (Hunink et al., 2001; Roberts et al., 2012; Weinstein et al., 2003). Additionally, when the long-term effectiveness data are missing, one can consider using decision-analytic modeling in order to assist decision makers (Hunink et al., 2001). In the identified studies, the time horizon ranged between 20 years and a lifetime, while one analysis did not explicitly report the time horizon used (Pandya et al., 2014).

Cost-effectiveness analysis (CEA): The main aim of using CEA is to assist decision-making or contributing in a policy discussion for resource allocation by providing information concerning the relative worth of an intervention per unit of cost in a limited budget (Hunink, 2001). To compare one treatment strategy with the next strategy that has higher efficiency and lower costs, the incremental cost-effectiveness ratios (ICER) or incremental costutility ratio (ICUR) are calculated (Weinstein et al., 2003; Weinstein and Stason, 1977). Not always the strategy with the lowest ICER is the most cost-effective strategy, as de-

Table 1. Overview of methodological characteristics and results of the published decision-analytic models identified

\begin{tabular}{|c|c|c|c|c|c|c|c|}
\hline $\begin{array}{l}\text { Reference, } \\
\text { country }\end{array}$ & $\begin{array}{l}\text { Economic } \\
\text { evaluation }\end{array}$ & Perspective & $\begin{array}{l}\text { Health } \\
\text { outcomes } \\
\text { evaluated }\end{array}$ & $\begin{array}{l}\text { Model } \\
\text { validation }\end{array}$ & $\begin{array}{l}\text { Sensitivity } \\
\text { analysis }\end{array}$ & $\begin{array}{l}\text { Modelling } \\
\text { approach }\end{array}$ & $\begin{array}{l}\text { Evaluated } \\
\text { time } \\
\text { horizon }\end{array}$ \\
\hline
\end{tabular}

\begin{tabular}{|c|c|c|c|c|c|c|c|c|}
\hline $\begin{array}{l}\text { Blommstein } \\
\text { et al. } 2015 \text {, } \\
\text { Netherlands }\end{array}$ & CEA, CUA & $\begin{array}{l}\text { Societal } \\
\text { perspective }\end{array}$ & $\begin{array}{l}\text { Median and } \\
\text { average } \\
\text { overall } \\
\text { survival; } \\
\text { QALYs }\end{array}$ & $\begin{array}{l}\text { Internal } \\
\text { validity; } \\
\text { Discussion: } \\
\text { Overlapping } \\
\text { survival } \\
\text { curves. }\end{array}$ & PSA & $\begin{array}{l}\text { Patient-level } \\
\text { simulation } \\
\text { (PLS) model }\end{array}$ & Lifetime & $\begin{array}{l}\text { MP, T, BorD, } \\
\text { R and others. } \\
\text { Combinations } \\
\text { (most } \\
\text { prescribed): } \\
\text { MP-T-Bor, MP- } \\
\text { T-R, T-Bor-R } \\
\text { and T-R-Bor }\end{array}$ \\
\hline $\begin{array}{l}\text { Cooper et al. } \\
2014, \text { UK }\end{array}$ & CEA, CUA & $\begin{array}{l}\text { NHS and } \\
\text { Personal } \\
\text { Social } \\
\text { Service } \\
\text { perspective }\end{array}$ & $\begin{array}{l}\text { Duration in } \\
\text { the healthy } \\
\text { states, } \\
\text { QALYs, }\end{array}$ & $\begin{array}{l}\text { Validation } \\
\text { reported }^{\mathrm{a}}\end{array}$ & $\begin{array}{l}\text { DSA } \\
\text { PSA }\end{array}$ & $\begin{array}{l}\text { Survival } \\
\text { analysis } \\
\text { approach } \\
\text { and partition } \\
\text { survival } \\
\text { analysis }\end{array}$ & Lifetime & $\begin{array}{l}\text { MPT, Bor-MP, } \\
\text { and CP-T - } \\
\text { Dexa vs. MP }\end{array}$ \\
\hline $\begin{array}{l}\text { Picot et al. } \\
2011, \text { UK }\end{array}$ & CEA, CUA & $\begin{array}{l}\text { NHS and } \\
\text { Personal } \\
\text { Social } \\
\text { Service } \\
\text { perspective }\end{array}$ & $\begin{array}{l}\text { Duration in } \\
\text { the healthy } \\
\text { states, } \\
\text { QALYs, }\end{array}$ & $\begin{array}{l}\text { Validation } \\
\text { reported }^{\mathrm{a}}\end{array}$ & $\begin{array}{l}\text { DSA } \\
\text { PSA }\end{array}$ & $\begin{array}{l}\text { Survival } \\
\text { analysis } \\
\text { approach } \\
\text { and partition } \\
\text { survival } \\
\text { analysis }\end{array}$ & 30 years & $\begin{array}{l}\text { MPT, Bor-MP, } \\
\text { and CP-T - } \\
\text { Dexa vs. MP }\end{array}$ \\
\hline $\begin{array}{l}\text { Garrison et al. } \\
\text { 2013, USA }\end{array}$ & CEA, CUA & $\begin{array}{l}\text { U.S. payer's } \\
\text { perspective }\end{array}$ & LYs, QALYs & $\begin{array}{l}\text { No formal } \\
\text { model } \\
\text { validation } \\
\text { reported }^{\mathrm{b}}\end{array}$ & $\begin{array}{l}\text { DSA } \\
\text { PSA }\end{array}$ & $\begin{array}{l}\text { Markov cohort } \\
\text { model } \\
\text { 1-month cycle } \\
\text { length }\end{array}$ & 20 years & $\begin{array}{l}\text { BorMP vs. TMP } \\
\text { vs. } \mathrm{RMP}-\mathrm{R}^{\mathrm{c}}\end{array}$ \\
\hline $\begin{array}{l}\text { Pandya et al. } \\
2014, \text { USA }\end{array}$ & CUA & $\begin{array}{l}\text { US third } \\
\text { party payer } \\
\text { perspective }\end{array}$ & QALYs & $\begin{array}{l}\text { No formal } \\
\text { model } \\
\text { validation } \\
\text { reported }\end{array}$ & $\begin{array}{l}\text { One- and } \\
\text { two-way SA }\end{array}$ & Decision tree & n.a. & $\begin{array}{l}\text { Early } v s . \\
\text { delayed } \\
\text { stem cell } \\
\text { transplantation }\end{array}$ \\
\hline
\end{tabular}

CEA - cost-effectiveness analysis; CUA - cost-utility analysis; PSA - probabilistic sensitivity analysis; DSA - deterministic sensitivity analysis; MP melphalan-prednisone; T - thalidomide; Bor - bortezomib; R - lenalidomide; NHS - National Health Service; QALYs - quality-adjusted life years; LY life years; SA - sensitivity analysis; n.a. - not available; n.r. - not reported.

${ }^{\text {a } V a l i d a t e d ~ b y ~ c h e c k i n g ~ t h e ~ m o d e l ~ s t r u c t u r e, ~ c a l c u l a t i o n s ~ a n d ~ d a t a ~ i n p u t s ~ f o r ~ t e c h n i c a l ~ c o r r e c t n e s s ; ~}{ }^{\mathrm{b}}$ Reported comparison with other cost estimates; ${ }^{\mathrm{c}}$ With continuous lenalidomide maintenance treatment 
Table 2. (Continued from Table 1) Overview of methodological characteristics and results of the published decision-analytic models identified

\begin{tabular}{|c|c|c|c|c|c|}
\hline $\begin{array}{l}\text { Reference, } \\
\text { country }\end{array}$ & Targeted population & Health states & $\begin{array}{l}\text { Currency, } \\
\text { index year }\end{array}$ & $\begin{array}{c}\text { Annual } \\
\text { discount rate }\end{array}$ & $\begin{array}{l}\text { Cost-effectiveness/ utility } \\
\text { relation }\end{array}$ \\
\hline $\begin{array}{l}\text { Blommstein } \\
\text { et al. } 2015, \\
\text { Netherlands }\end{array}$ & $\begin{array}{l}\text { phase: patients who } \\
\text { received treatment for } \mathrm{MM}, \\
\text { nontransplant eligible; age base } \\
\text { case: } \geq 66 \text { yrs }\end{array}$ & n.a. & $\begin{array}{l}\text { EU } € \\
2014\end{array}$ & $\begin{array}{l}\text { Benefit: } 1.5 \\
\% \text { and costs: } \\
4 \%\end{array}$ & $\begin{array}{l}\text { ICUR discounted: } \\
\text { T-R-V €34,875/QALY; } \\
\text { ICER discounted: T-R-V } \\
€ 24,618 / \mathrm{LY}\end{array}$ \\
\hline $\begin{array}{l}\text { Cooper et al. } \\
2014, U K\end{array}$ & $\begin{array}{l}\text { phase: newly diagnosed patients } \\
\text { with MM ineligible for HDT- } \\
\text { SCT; age base case: n.r. }\end{array}$ & $\begin{array}{l}\text { Pre-progression without AEs, } \\
\text { pre-progression with AEs, } \\
\text { Post progression, } \\
\text { Death }\end{array}$ & $\begin{array}{l}\text { EUR } € \text {, } \\
\text { estimated } \\
2009\end{array}$ & $\begin{array}{l}\text { Benefit and } \\
\text { costs: } 3.5 \%\end{array}$ & $\begin{array}{l}\text { ICUR discounted: MP vs. } \\
\text { MPT: } \\
€ 10,962 / \mathrm{QALY} \text {; MP vs. VMP: } \\
€ 35,8784 / \mathrm{QALY}\end{array}$ \\
\hline $\begin{array}{l}\text { Picot et al. } \\
2011, U K\end{array}$ & $\begin{array}{l}\text { phase: newly diagnosed patients } \\
\text { with MM ineligible for HDT- } \\
\text { SCT; age base case: n.r. }\end{array}$ & $\begin{array}{l}\text { Pre-progression without AEs, } \\
\text { Preprogression with AEs, } \\
\text { Post progression, } \\
\text { Death }\end{array}$ & $\begin{array}{l}\text { UK } £ \text {, } \\
\text { estimated } \\
2009\end{array}$ & $\begin{array}{l}\text { Benefit and } \\
\text { costs: } 3.5 \%\end{array}$ & $\begin{array}{l}\text { ICUR discounted: MP vs. } \\
\text { MPT: } \\
£ 9,135 / \text { QALY; } \\
\text { MP vs. VMP: } £ 29,820 / \text { QALY; } \\
\text { MP vs. CTDa: } £ ~ 33,031 / \text { QALY }\end{array}$ \\
\hline $\begin{array}{l}\text { Garrison et } \\
\text { al. 2013, USA }\end{array}$ & $\begin{array}{l}\text { phase: previously untreated } \\
\text { transplant ineligible MM } \\
\text { patients; age base case: } 70 \mathrm{yrs}\end{array}$ & $\begin{array}{l}\text { Stable disease/ } \\
\text { minimal response, } \\
\text { Partial response, } \\
\text { Complete response, } \\
\text { Treatment-free interval } \\
\text { for VMP and MPT or } \\
\text { MPR, Progressive disease, } \\
\text { Second-line therapy, Death }\end{array}$ & $\begin{array}{l}\text { US \$, } \\
2012\end{array}$ & $\begin{array}{l}\text { Benefit and } \\
\text { costs: } 3 \%\end{array}$ & $\begin{array}{l}\text { ICER discounted: VMP vs. MP: } \\
\text { \$ 42,169/LY; } \\
\text { ICUR discounted: VMP vs. MP: } \\
\text { \$ 59,076/ QALY; } \\
\text { VMP vs. MPT: VMP cost } \\
\text { saving; VMP vs. } \\
\text { MPR-R: VMP cost saving }\end{array}$ \\
\hline $\begin{array}{l}\text { Pandya et al. } \\
2014 \text {, USA }\end{array}$ & $\begin{array}{l}\text { phase: newly diagnosed } \\
\text { patients with MM, treated with } \\
\text { immunomodulatory drugs } \\
\text { from } 2001 \text { to } 2008 \text {; } \\
\text { age-base case: n.r. }\end{array}$ & $\begin{array}{l}\text { Survive, Refractory, } \\
\text { Response, Complete } \\
\text { Remission, Partial } \\
\text { Remission, No relapse, } \\
\text { Relapse, Die }\end{array}$ & US \$ 2012 & $\begin{array}{l}\text { Costs and } \\
\text { outcomes: } \\
0-7 \%\end{array}$ & n.r. \\
\hline
\end{tabular}

cision-making authorities may want to spend more costs to gain a certain health benefit. To that point, the ratios are compared to a country-specific defined threshold, to determine the most cost-effective strategy (i.e. strategy with the ICER that is closest to the threshold defined that is not going over the defined limit is considered cost-effective). As defined by NICE, the threshold "represents the additional cost that has to be imposed on the system to gain 1 QALY worth of health through displacement" or a willingness-topay value for an additional gain in QALY (Siebert, 2003; Weinstein et al., 2003; Weinstein and Stason, 1977). Another important concept in conducting CEA is discounting where future costs are converted to their present value, as "in general, individuals and society have a positive rate of time preference for consumption now over consumption in the future" (Hunink et al., 2001; Siebert, 2003). The value of the discount rate is usually defined by national agencies that conduct economic evaluation guidelines for a specific country. In the actual review, one study compared early or delayed ASCT administration and reported that early ASCT cohort had a benefit of 1.96 QALYs (0.23 QALYs more than delayed ASCT), implying that early ASCT is the preferred (dominant) strategy over delayed ASCT, taking in consideration that the costs are also lower $(\$ 249,236$ and $\$ 262,610$, respectively). Two additional studies evaluated melphalan-prednisone-thalidomide (MPT), bortezomib- melphalan-prednisone (BorMP), and cyclophosphamidethalidomide-dexamethasone (CTP) vs. melphalan-prednisone (MP) (Cooper et al., 2014; Picot et al., 2011). Picot et al. reported that MPT represents a cost-effective use of the resources compared with MP as a first-line therapy for people with MM (not eligible for high-dose therapy and/or are aged over 65 years). However, when comparing MPT and BorMP, it was stated that there was a negligible clinical benefit from BorMP at an additional cost that resulted in the ICERs exceeding $£ 300,000$ per QALYs (Picot et al., 2011). Cooper et al. reported for BorMP vs. MPT an estimated ICER of EUR 14,288 (model for Janssen-Cilag), and EUR 364,614 (model for Celgene) per QALYs gained (Cooper et al., 2014). Additionally, Garrison et al. reported that bortezomib-melphalan-thalidomide combination is cost-effective compared with MP, MPT, and melphalanprednisone-lenalidomide, with lenalidomide maintenance (Garrison et al., 2013).

Sensitivity analyses: Usually all parameters used to populate a decision-analytic model are not the "perfect" values found in the "perfect" world and decision makers should always consider the impact of the uncertainty on the results. Thus, it is recommendable, sensitivity analyses to be performed (Briggs, A.H. et al., 2012). Studies included in the actual review reported sensitivity analyses, including deterministic or/and probabilistic sensitivity analyses. 
Table 3. Overview of health utility data identified from the published literature

\begin{tabular}{|c|c|c|c|c|}
\hline Reference & Treatment & Follow-up period & Additional references & Utility value \\
\hline \multirow[t]{2}{*}{ Pandya et al., 2014} & Early and delayed ASCT & $12-30$ months & $\begin{array}{l}\text { (Segeren et al., 2003; van } \\
\text { Agthoven et al., 2004) }\end{array}$ & $0.7^{\mathrm{a}}$ \\
\hline & First-line treatment & & & 0.63 \\
\hline \multirow[t]{3}{*}{ Acaster et al., 2013} & Second-line treatment & n.r. & / & 0.67 \\
\hline & Later stage & & & 0.63 \\
\hline & VAD/VAMP & Baseline ( 2 weeks) & & 0.52 \\
\hline \multirow[t]{2}{*}{ Uyl-de Groot et al., 2005} & Hospital discharge following PSCT & 12 months & / & 0.69 \\
\hline & Hospital discharge following PSCT & $\begin{array}{l}6 \text { months } \\
\text { After relapse }\end{array}$ & \multirow[b]{2}{*}{$\begin{array}{l}\text { (Gulbrandsen et al., 2001; } \\
\text { Mujica-Mota, Bagust and } \\
\text { Haycox, 2004; Nord et al., } \\
\text { 1997; van Agthoven et al., } \\
\text { 2004) }\end{array}$} & $\begin{array}{c}0.64 \\
0.645\end{array}$ \\
\hline Hornberger et al., 2010 & $\begin{array}{l}\text { Bor, } \mathrm{RD} \text {, and } \\
\mathrm{D} \text { alone }\end{array}$ & Prior to relapse & & 0.81 \\
\hline Blommestein et al., 2015 & $\begin{array}{l}\text { MP, T-based, Bor-based, R-based; and } \\
\text { other treatments }\end{array}$ & 50 months & -5 & $0.76^{\mathrm{b}}$ \\
\hline \multirow{6}{*}{ van Agathoven et al., 2004} & \multirow{3}{*}{$\begin{array}{l}\text { Intensive chemotherapy only (VAD } \\
\text { remission-induction chemotherapy) }\end{array}$} & 6 months & \multirow{6}{*}{ (Segeren et al., 2003) } & $\begin{array}{l}0.81 \\
0.65\end{array}$ \\
\hline & & 12 months & & 0.8 \\
\hline & & & & $\begin{array}{l}0.62 \\
0.81\end{array}$ \\
\hline & \multirow{3}{*}{$\begin{array}{l}\text { Myeloablative chemotherapy and } \\
\text { autologous stem-cell transplantation }\end{array}$} & 18 months & & $\begin{array}{l}0.01 \\
0.69\end{array}$ \\
\hline & & 24 months & & 0.77 \\
\hline & & 24 months & & 0.75 \\
\hline \multirow{2}{*}{ Delforge et al., 2015} & $\mathrm{RD}$ & Baseline & \multirow{2}{*}{ / } & $0.5^{\mathrm{c}}$ \\
\hline & MPT & 18 months & & $0.6-0.65$ \\
\hline
\end{tabular}

VAD - vincristine, adriamycin, dexamethasone; VAMP - vincristine, adriamycin and methylprednisone; ASCT - autologous stem cell transplantation; PST - peripheral stem cell transplantation; T - thalidomide, TD - thalidomide, dexamethasone; Bor - bortezomib, RD - lenalidomide, dexamethasone; MP melphalan, prednisone; MPT - melphalan, prednisone, thalidomide; n.r.- not reported

${ }^{a}$ To the value of 0.8 ('general utility value'), a correction factor of $-19.5 \%$ should be applied, for patients who were in an undefined state following intentionally curative primary therapy

${ }^{\mathrm{b}}$ Average utility value

${ }^{\mathrm{c} A l l}$ values mean

\section{Health utility data identified}

Utility values available in the identified literature in the actual SLS are summarized in Table 3. Only four studies give a real-world data from the surveys reported (Acaster et al., 2013; Blommestein et al., 2016; Delforge et al., 2015; Uyl-de Groot et al., 2005). The other three studies used data published before or calculated data (explicitly details explained in the legend of Table 3 ). The utility values differ based on the treatment strategy, as well as the follow-up period or baseline assessment.

Van Agathoven et al. reported utility values in a range between $0.62-0.81$ for the period of $6,12,18$ and 24 months of intensive chemotherapy only (with vincristineadriamycin-dexamethasone remission-induction chemotherapy) and separately with myeloablative chemotherapy and ASCT (van Agthoven et al., 2004). Additionally, Hornberger et al. reported utility of 0.81 prior to relapse with treatment strategies, including bortezomib, lenalidomide-dexamethasone, and dexamethasone alone and 0.645 utility value after relapse (Hornberger et al., 2010). Blom- mestein et al. reported an average utility value of 0.76 for the combinations as MP, thalidomide-based, bortezomibbased, and lenalidomide-based (Blommestein et al., 2015). Delforge et al., as a baseline analysis, reported utility of 0.5 for lenalidomide-dexamethasone and MPT combinations, with an increase of the utility value in a range of $0.6-0.65$ after a follow-up of 18 months (Delforge et al., 2015).

\section{Utility estimations}

From 25 patients, evaluations only from 20 patients were received. Their evaluations and the data reported from the EQ-5D-5L profiles are summarized in Table 4. One can observe that the health of some patients evaluated is with very low utility value, near to 0 . In those cases, one can assume that the patients were evaluated after the SCT or after treatment for the adverse events of the high dose chemotherapy. The average utility calculated was 0.723 for combination treatments, bortezomib- and/or thalidomidebased. 
Table 4. An overview of the real-world health utility data from Hematological Clinical Center in Skopje

\begin{tabular}{cc}
\hline \hline EQ-5D-5L profile & EQ-5D-5L index value \\
\hline 11111 & 1.000 \\
11111 & 1.000 \\
32312 & 0.638 \\
11111 & 1.000 \\
11112 & 0.932 \\
44444 & 0.049 \\
11413 & 0.707 \\
11111 & 1.000 \\
21213 & 0.770 \\
21123 & 0.756 \\
44454 & 0.096 \\
12324 & 0.477 \\
11112 & 0.932 \\
12213 & 0.746 \\
11112 & 0.932 \\
Utility calculated & 0.723 \\
(average value) & \\
\hline
\end{tabular}

\section{Discussion}

In the actual review for identifying decision-analytic modeling studies that compare different MM treatment combinations, different studies were identified, using different mathematical models. In part of them only, the choice for the respective model was explicitly explained. Two studies applied SPMs. Based on the summarized data, one can assume that is the best to develop a model that combines different novel agent combinations in $\mathrm{MM}$ treatment in different health states. Regarding the literature guidance and the nature of the disease, the modelers should take care to develop such a mathematical model that could get in more relation with the nature of the disease. Additionally, the model should be created in a way that could be transferable to another data set or country specific data and meet the criteria of Good Modeling Research Practices Guidelines, such as the ISPOR-SMDM Modeling Good Research Practices Task Forces 1, 2, 3, 6 and 7 and the Consolidated Health Economic Evaluation Reporting Standards (Husereau et al.) (Briggs, A. et al., 2012; Caro et al., 2012; Eddy et al., 2012; Husereau et al., 2013; Roberts et al., 2012; Siebert et al., 2012).

In this review, the mostly used time horizon was identified, being 20 years to lifetime. A lifelong time horizon is found to be the most appropriate for modeling outcomes of cancer diseases, as it captures QALYs gained from prevented or delayed death as well as all healthrelated events during the lifetime period until death.

Regarding the identified utility data from the SLS, only five studies reported utility values relevant to our search criteria. Different national health technology agencies have different standards in choosing the appropriate patient-outcome instrument (e.g., VAS, interview, generic preference-based) to measure the health outcomes and transfer them to HUVs.

The average utility value calculated from the realworld data from Macedonia (0.723) for the treatment combinations of thalidomide and/or bortezomib is comparable with the utility value reported in Blommestein et al., with average utility value of 0.76 for the combinations based on thalidomide and/or bortezomib evaluated in Netherlands (Blommestein et al., 2016). Those values are slightly different with the results reported from Hornberger et al. and Delforge et al. that report utility value for the same treatment based combinations (Hornberger et al., 2010; Delforge et al., 2015). The difference in the utility values is less than $0.1 \mathrm{HUV}$. One can assume that these differences result from the different populations as well as follow-up periods.

The actual research has several limitations. Articles that were not published in English are not included. The literature search was limited only to published full-text studies in only one database. Therefore, there is possibility some publications of decision-analytic models or HUVs that meet the selection criteria to be missed, if published in different databases, different languages or only as abstracts.

\section{Conclusion}

From the primary literature search some of the most frequent modeling techniques (decision tree, Markov model, SPMs), used in treating specific target groups with MM, were identified. The identified studies were published between 2000 and 2015, documenting different treatment strategies in MM. Based on the research, one can observe that different modeling studies that measure treatment effects and costs of MM are available; emphasizing the importance of decision-analytic modeling in assisting health policy decision making when considering treatment of MM patients. For further development in the decisionanalytic modeling, a modeling approach should be more based on the international guidelines for reporting decisionanalytic modeling and their evaluation. This would further lead to quality improvement and higher impact of developing models for decision making. Using those economic evaluations in valuing health care interventions would further improve the involvement of decision-analytic techniques when making decisions in the Macedonian health care system. Additionally, an overview of HUVs for different treatment combinations gives an insight of the role of valuing health effects using the generic preferencebased instruments during the clinical practice. The survey 
conducted in Macedonia, evaluating the HUV of patients treated with bortezomib and/or thalidomide combinations and its comparison with the published literature values shows that there should be organized self-evaluation surveys in the University clinical center in Skopje during the daily care in different follow-up periods, where patients will be able to assess their health conditions after a specific treatment; thus, helping in collecting the needed evidence for conducting in the future a relevant cost-effectiveness model for treatment strategies in cancer diseases in general or in MM patients, more specifically.

\section{Acknowledgements}

This work was part of a doctoral degree thesis and was supervised by Professor Ljubica Suturkova. All other co-authors assisted in language proofreading, writing, scientific opinions, and inputs. The project was partially funded (scholarship training abroad for the main author: Vjollca Qerimi) through Erasmus Mundus Western Balkans (ERAWEB), a project funded by the European Commission.

\section{References}

Acaster, S., Gaugris, S., Velikova, G., Yong, K., and Lloyd, A. J., 2013. Impact of the treatment-free interval on health-related quality of life in patients with multiple myeloma: a UK cross-sectional survey. Support Care Cancer 21(2), 599-607.

Adam, Z., 1993. Therapy of refractory multiple myeloma. II. Therapy using high doses of alkylating cytostatic agents and radiotherapy in addition to interferon and bone marrow transplantation]. Vnitr. Lek. 39(4), 385-400.

Blade, J., Samson, D., Reece, D., Apperley, J., Bjorkstrand, B., Gahrton, G., Gertz, M., Giralt, S., Jagannath, S., and Vesole, D., 1998. Criteria for evaluating disease response and progression in patients with multiple myeloma treated by high-dose therapy and haemopoietic stem cell transplantation. Myeloma Subcommittee of the EBMT. European Group for Blood and Marrow Transplant. Br. J. Haematol. 102(5), 1115-1123.

Blommestein, H. M., Verelst, S. G., de Groot, S., Huijgens, P. C., Sonneveld, P., Uyl-de Groot, C. A., 2016. A costeffectiveness analysis of real-world treatment for elderly patients with multiple myeloma using a full disease model. Eur. J. Haematol. 96(2), 198-208.

Briggs, A. H., Weinstein, M. C., Fenwick, E. A., Karnon, J., Sculpher, M. J., Paltiel, A. D., and Force, Ispor-Smdm Modeling Good Research Practices Task, 2012. Model parameter estimation and uncertainty analysis: a report of the ISPOR-SMDM Modeling Good Research Practices Task Force Working Group-6. Med. Decis. Making 32(5), $722-$ 732.

Briggs, A., Weinstein, M. C., Fenwick, E. A., Karnon, J., Sculpher, M. J., Paltiel, A. D., Force, on Behalf of the ISPOR-SMDM Modeling Good Research Practices Task, 2012. Model Parameter Estimation and Uncertainty: A Report of the ISPOR-SMDM Modeling Good Research Practices Task
Force-6 [Plus Editorial]. Medical Decision Making 32, 722732.

Caro, J. J., 2005. Pharmacoeconomic analyses using discrete event simulation. Pharmacoeconomics 23(4), 323-332.

Caro, J. J., Briggs, A.H., Siebert, U., Kuntz, K.M., and on behalf of the ISPOR-SMDM Modeling Good Research Practices Task Force, 2012. Modeling Good Research Practices Overview: A Report of the ISPOR-SMDM Modeling Good Research Practices Task Force -1. Medical Decision Making 32(5), 667-677.

Cooper, K., Picot, J., Bryant, J., and Clegg, A., 2014. Comparative cost-effectiveness models for the treatment of multiple myeloma. Int. J. Technol. Assess Health Care 30(1), 90-97.

Delforge, M., Minuk, L., Eisenmann, J. C., Arnulf, B., Canepa, L., Fragasso, A., Leyvraz, S., Langer, C., Ezaydi, Y., Vogl, D. T., Giraldo-Castellano, P., Yoon, S. S., Zarnitsky, C., Escoffre-Barbe, M., Lemieux, B., Song, K., Bahlis, N. J., Guo, S., Monzini, M. S., Ervin-Haynes, A., Houck, V., Facon, T., 2015. Health-related quality-of-life in patients with newly diagnosed multiple myeloma in the FIRST trial: lenalidomide plus low-dose dexamethasone versus melphalan, prednisone, thalidomide. Haematologica 100(6), 826-833.

Eddy, D. M., Hollingworth, W., Caro, J. J., Tsevat, J., McDonald, K. M., Wong, J. B., Force, Ispor-Smdm Modeling Good Research Practices Task, 2012. Model transparency and validation: a report of the ISPOR-SMDM Modeling Good Research Practices Task Force-7. Med Decis Making 32(5), 733-743.

Garrison, L. P., Jr., Wang, S. T., Huang, H., Ba-Mancini, A., Shi, H., Chen, K., Korves, C., Dhawan, R., Cakana, A., van de Velde, H., Corzo, D., Duh, M. S., 2013. The costeffectiveness of initial treatment of multiple myeloma in the U.S. with bortezomib plus melphalan and prednisone versus thalidomide plus melphalan and prednisone or lenalidomide plus melphalan and prednisone with continuous lenalidomide maintenance treatment. Oncologist 18(1), 27-36.

Group, EuroQol, 1990. EuroQol Group. EuroQol-a new facility for the measurement of health-related quality of life. Health Policy 1990, 16, 199-208..

Group, EuroQol., 2014. EuroQol Group. EQ-5D-5L Value Sets. http://www.euroqol.org/about-eq-5d/valuation-of-eq-5d/eq5d-51-valuesets. html; 2014.

Gulbrandsen, N., Wisloff, F., Brinch, L., Carlson, K., Dahl, I. M., Gimsing, P., Hippe, E., Hjorth, M., Knudsen, L. M., Lamvik, J., Lenhoff, S., Lofvenberg, E., Nesthus, I., Nielsen, J. L., Turesson, I., Westin, J., Nordic Myeloma Study, Group, 2001. Health-related quality of life in multiple myeloma patients receiving high-dose chemotherapy with autologous blood stem-cell support. Med. Oncol. 18(1), 65-77.

Howlade, N., Noone, A., and Krapcho, M. , 2011. SEER Cancer Statistics Review, 1975- 2009 (Vintage 2009 Populations), Bethesda, MD: National Cancer Institute. Bethesda, MD. Available at: http://seer.cancer.gov/csr/1975_2009_pops09/, based on November 2011 SEER data submission, posted to the SEER web site, 2012.

Hunink, M.G.M., Glasziou, P.P., Siegel, J.E., Weeks, J.C., Pliskin, J.S., Elstein, A.S., Weinstein, M.C., 2001. Decision making in health and medicine: integrating evidence and values. Cambridge University Press.

Husereau, D., Drummond, M., Petrou, S., Carswell, C., Moher, D., Greenberg, D., Augustovski, F., Briggs, A. H., Mauskopf, J., Loder, E., and Force, Cheers Task, 2013. Consolidated 
Health Economic Evaluation Reporting Standards (CHEERS) statement. Value Health 16(2), e1-5.

Karnon, J., Stahl, J., Brennan, A., Caro, J. J., Mar, J., Moller, J., Force, Ispor-Smdm Modeling Good Research Practices Task, 2012. Modeling using discrete event simulation: a report of the ISPOR-SMDM Modeling Good Research Practices Task Force--4. Value Health 15(6), 821-827.

Kumar, S., Karan, R., Kapoor, S., S, P. S., and S, K. K., 2012. Screening and isolation of halophilic bacteria producing industrially important enzymes. Braz. J. Microbiol. 43(4), 1595-1603.

Longworth, L., and Rowen, D., 2013. Mapping to obtain EQ-5D utility values for use in NICE health technology assessments" Value Health 16(1), 202-210.

Moreau, P., San Miguel, J., Ludwig, H., Schouten, H., Mohty, M., Dimopoulos, M., Dreyling, M., Group, Esmo Guidelines Working, 2013. Multiple myeloma: ESMO Clinical Practice Guidelines for diagnosis, treatment and follow-up. Ann. Oncol. 24( 6), vi133-137.

Moreau, P., and Touzeau, C., 2015. Multiple myeloma: from front-line to relapsed therapies. Am. Soc. Clin. Oncol. Educ. Book e504-511.

Mujica-Mota, R., Bagust, A., and Haycox, A., 2004. Mapping health-related quality of life (HRQOL) measurements into generic utility measures (EQ-5D): a case study with bortezomib (Velcade). Value Health 7: 683 (abst).

Nord, E., Wisloff, F., Hjorth, M., and Westin, J., 1997. Costutility analysis of melphalan plus prednisone with or without interferon-alpha $2 b$ in newly diagnosed multiple myeloma. Results from a randomised controlled trial. Pharmacoeconomics 12(1), 89-103.

Palumbo, A., and Anderson, K., 2011. "Multiple myeloma". N Engl J Med 364(11), 1046-1060.

Palumbo, A., Bringhen, S., Ludwig, H., Dimopoulos, M. A., Blade, J., Mateos, M. V., Rosinol, L., Boccadoro, M., Cavo, M., Lokhorst, H., Zweegman, S., Terpos, E., Davies, F., Driessen, C., Gimsing, P., Gramatzki, M., Hajek, R., Johnsen, H. E., Leal Da Costa, F., Sezer, O., Spencer, A., Beksac, M., Morgan, G., Einsele, H., San Miguel, J. F., and Sonneveld, P., 2011. Personalized therapy in multiple myeloma according to patient age and vulnerability: a report of the European Myeloma Network (EMN). Blood 118(17), 4519-4529.

Palumbo, A., Rajkumar, S. V., San Miguel, J. F., Larocca, A., Niesvizky, R., Morgan, G., Landgren, O., Hajek, R., Einsele, H., Anderson, K. C., Dimopoulos, M. A., Richardson, P. G., Cavo, M., Spencer, A., Stewart, A. K., Shimizu, K., Lonial, S., Sonneveld, P., Durie, B. G., Moreau, P., Orlowski, R. Z., 2014. International Myeloma Working Group consensus statement for the management, treatment, and supportive care of patients with myeloma not eligible for standard autologous stem-cell transplantation. J. Clin. Oncol.32(6), 587-600.

Pandya, C., Hashmi, S., Khera, N., Gertz, M. A., Dispenzieri, A., Hogan, W., Siddiqui, M., Noyes, K., Kumar, S. K., 2014. Cost-effectiveness analysis of early vs. late autologous stem cell transplantation in multiple myeloma. Clin. Transplant 28(10), 1084-1091.

Picot, J., Cooper, K., Bryant, J., Clegg, A. J., 2011. The clinical effectiveness and cost-effectiveness of bortezomib and thalidomide in combination regimens with an alkylating agent and a corticosteroid for the first-line treatment of multiple myeloma: a systematic review and economic evaluation. Health Technol. Assess 15(41), 1-204.

Roberts, M., Russell, L. B., Paltiel, A. D., Chambers, M., McEwan, P., Krahn, M., and on Behalf of the ISPORSMDM Modeling Good Research Practices Task Force, 2012. Conceptualizing a Model: A Report of the ISPORSMDM Modeling Good Research Practices Task Force -2. Medical Decision Making 32, 678-689.

Rochau, U., Jahn, B., Qerimi, V., Burger, E. A., Kurzthaler, C., Kluibenschaedl, M., Willenbacher, E., Gastl, G., Willenbacher, W., and Siebert, U., 2015. Decision-analytic modeling studies: An overview for clinicians using multiple myeloma as an example". Crit. Rev. Oncol. Hematol. 94(2), 164-178.

Segeren, C. M., Sonneveld, P., van der Holt, B., Vellenga, E., Croockewit, A. J., Verhoef, G. E., Cornelissen, J. J., Schaafsma, M. R., van Oers, M. H., Wijermans, P. W., Fibbe, W. E., Wittebol, S., Schouten, H. C., van Marwijk Kooy, M., Biesma, D. H., Baars, J. W., Slater, R., Steijaert, M. M., Buijt, I., Lokhorst, H. M., Dutch-Belgian Hemato-Oncology Cooperative Study, Group, 2003. Overall and event-free survival are not improved by the use of myeloablative therapy following intensified chemotherapy in previously untreated patients with multiple myeloma: a prospective randomized phase 3 study. Blood 101(6), 2144-2151.

Siebert, U., 2003. When should decision-analytic modeling be used in the economic evaluation of health care? [Editorial]. European Journal of Health Economics 4(3), 143-150.

Siebert, U., Alagoz, O., Bayoumi, A. M., Jahn, B., Owens, D. K., Cohen, D. J., Kuntz, K. M., 2012. "State-transition modeling: a report of the ISPOR-SMDM Modeling Good Research Practices Task Force-3. Med. Decis. Making 32(5), 690-700.

Stojanoski, Z., Georgievski, B., Karanfiloski, O., GenadievaStavric, S., Pivkova, A., Cevreska, L. , 2013. Treatment with autologous stem cell transplantation in multiple myeloma patients - a 10 year single centre experience. Serbian Journal of Experimental and Clinical Research 14 (1), 13-18.

Uyl-de Groot, C. A., Buijt, I., Gloudemans, I. J., Ossenkoppele, G. J., Berg, H. P., and Huijgens, P. C., 2005. Health related quality of life in patients with multiple myeloma undergoing a double transplantation. Eur. J. Haematol. 74(2), 136-143.

van Agthoven, M., Segeren, C. M., Buijt, I., Uyl-de Groot, C. A., van der Holt, B., Lokhorst, H. M., and Sonneveld, P., 2004. A cost-utility analysis comparing intensive chemotherapy alone to intensive chemotherapy followed by myeloablative chemotherapy with autologous stem-cell rescue in newly diagnosed patients with stage II/III multiple myeloma; a prospective randomised phase III study. Eur. J. Cancer 40(8), 1159-1169.

Weinstein, M. C., O’Brien, B., Hornberger, J., Jackson, J., Johannesson, M., McCabe, C., and Luce, B. R., 2003. Principles of good practice for decision analytic modeling in health-care evaluation: report of the ISPOR Task Force on Good Research Practices--Modeling Studies. Value Health 6(1), 9-17.

Weinstein, M. C., and Stason, W. B., 1977. Foundations of costeffectiveness analysis for health and medical practices. N. Engl. J. Med. 296(13), 716-721. 


\section{Appendix A}

\section{A.1 Keywords applied:}

(myelom* OR multiple myeloma OR myelomatosis OR plasma cell myeloma OR kahler* disease) AND (decision anal* OR cost utility* OR cost benefit* OR cost mini* OR QALY OR quality adjusted life year* OR quality-adjusted life year* OR Markov OR Markov model* OR cost effectiveness* OR cost-effectiveness* OR decision model* OR decision tree*).

Mesh terms: multiple myeloma, decision support techniques, cost benefit analysis, quality adjusted life years, Markov chain, decision tree.

\section{Appendix B}

Здравствен прашалник EQ-5D-5L - Верзија на македонски јазик за Република Македонија

(Version in Macedonian for Macedonia)

Macedonia (Macedonian) C 2012 EuroQol Group EQ-5D ${ }^{\mathrm{TM}}$ is a trademark of the EuroQol Group

\section{A.2 Keywords applied:}

(myelom* OR multiple myeloma OR myelomatosis OR plasma cell myeloma OR kahler* disease) AND (utilit* OR "quality of life" OR QoL OR "quality adjusted life-years" OR "quality adjusted life years" OR "qualityadjusted life years" OR QALY* OR HRQoL OR EuroQoL5d OR EQ-5D).

MeSH terms: multiple myeloma, quality of life, qualityadjusted life years.

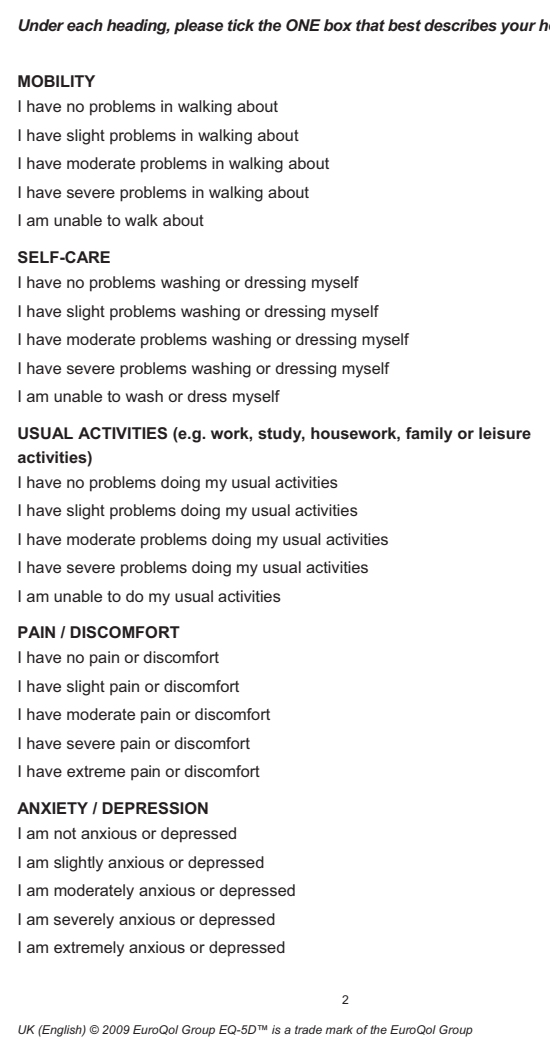

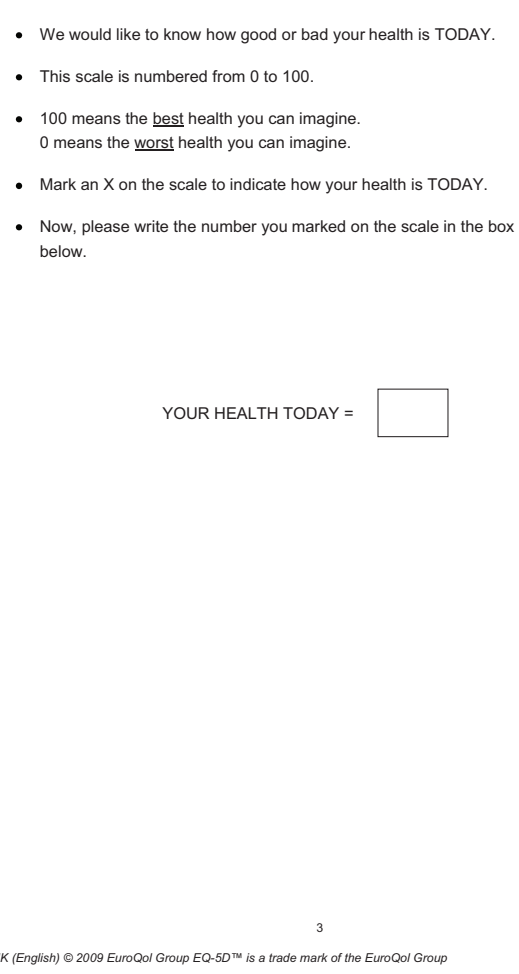
.

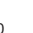
(1) :

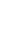

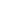

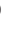

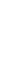




\title{
Преглед на анализи за трошок- ефективност, вредности на здравствена корисност кај Мултипла Миелома и проценка на здравствена корисност базирана на реални-податоци во Македонија
}

\author{
Вјолца Ќерими ${ }^{1,2}$, Александра Капедановска-Несторовска ${ }^{1}$, Зоран Стерјев ${ }^{1}$, \\ Соња Генадиева-Ставриќ ${ }^{3}$, Љубица Шутуркова ${ }^{1}$

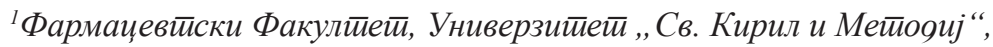 \\ Мајка Тереза 47, 1000 Скойје, Макеоонија; \\ ${ }^{2}$ Institute of Public Health, Medical Decision Making and Health Technology Assessment, Department of Public Health, \\ Health Services Research and Health Technology Assessment, UMIT-University for Health Sciences, \\ Medical Informatics and Technology, Eduard-Wallnöfer-Zentrum 1, 6060 Hall i.T., Austria; \\ ${ }^{3}$ Меоицински факулиетй, Универзииеийска Клиника за Хемайолоїија, Мајка Тереза 47, 1000 Скойје, Макеоонија
}

Клучни зборови: моделирање на анализа на одлуки, вредност на здравствената корисност, мултипен миелом, корисност, EQ-5D-5L

Мултипен миелом (МM) претставува хематолошко неопластично нарушување на плазматските клетки во коскената срцевина. Денес, преживувањето на пациентите со ММ е подобрено со користењето на нови терапии (пр. бортезомиб, талидомид). Аналитичките модели за одлучување (AMO) се многу корисни во донесувањето на одлуки во клиничката пракса и здравствената политика, со систематско оценување на очекуваните резултати од алтернативните третмани. При спроведување на АМО, Националниот институт за клиничка евалуација (Institute for Clinical Excellence, NICE) препорачува како најпосакувана рамка да се користат податоците за години на живот коригирани во однос на квалитетот како главна мерка за вреднување на здравствената состојба, кои се добиваат со користење на генерички инструменти.

Цел на актуелната студија е да се идентификуваат и анализираат структурните и методолошките пристапи на веќе објавени студии кои евалуираат: АМО за различни стратегии за третман на ММ и објавени вредности на здравствена корист (ВЗК) после третманот на ММ. Пребарувањата беа развиени во базата на податоци за електронска литература PubMed/MEDLINE. Податоците за ВЗК од тековниот третман на пациенти со ММ во Република Македонија беа добиени од Клиниката за хематологија во Скопје. Во периодот јануари-ноември 2016 година беше спроведена анкета со која беа собирани национални податоци за В3К, користејќи го генеричкиот инструмент EQ-5D-5L, применет на 20 ММ пациенти.

Од идентификуваните студии, само пет користеле АМО. Седум студии беа вклучени во извлекувањето на веќе објавените ВЗК. Пресметаната национална здравствена корист беше 0,723 ; споредлива со објавените податоци во претходно идентификуваните студии за слични протоколи за третман на ММ.

Во актуелната студија беа идентификувани неколку пристапи за моделирање и ВЗК, развиени за различни стратегии за третман и целни групи во ММ. Овие податоци може да се користат за параметризација на АМО за третман на МM. 